\title{
FRONT PEMBELA ISLAM: Antara Kekerasan dan Kematangan Beragama
}

\author{
Fahruddin Faiz \\ UIN Sunan Kalijaga Yogyakarta \\ Fahruddin_faiz@yahoo.com
}

\begin{abstract}
Abstrak
Meskipun mengandung kontradiksi dan paradok secara logis, namun kekerasan atas nama agama tidak sukar untuk ditemukan sepanjang sejarah peradaban manusia. Paradok yang dimaksud tampak dalam pertentangan antara idealitas agama sebagai yang mengajarkan nilainilai luhur, dengan adanya beberapa kelompok atau individu di tengah masyarakat yang dengan mengatasnamakan agama malah berbuat kekerasan dan kerusakan. FPI (Front Pembela Islam) yang berkembang di Indonesia banyak dikategorikan sebagai contoh dalam kasus ini. Di luar faktor komitmen beragama dan pengaruh sosial-budaya-politikekonomi, kesediaan seseorang untuk melakukan kekerasan hakikatnya berhubungan dengan dimensi psikologisnya, yaitu kematangan spiritual atau kematangan beragamanya. Tulisan ini mencoba mengurai sejauhmana perilaku kekerasan sebagaimana sering diperagakan oleh FPI memiliki korelasi dengan tingkat kematangan beragama.
\end{abstract}

\section{Abstract}

ISLAMIC DEFENDERS FRONT (FPI) : BETWEEN VIOLENCES AND RELIGIOUS MATURITY. Despite its contradiction and logically paradox, violence in the name of religion is not difficult to be found throughout the history of human civilization. The paradox meant here is the contradiction between the ideals of religion that teaches the noble values on the one hand and the tendency of certain religious groups or individuals doing the violence and destruction under the name of religion. In Indonesia, the FPI (the Islamic Defenders Front) is an example of such. In addition to religious commitment and the influences of socio-cultural, political, economic factors, one's willingness to commit violence is intrinsically linked to the psychological dimension, i.e spiritual maturity. This study attempts to examine the correlation between the violent tendencies exhibited by the FPI with the level of religious maturity of the group.

Kata Kunci: FPI; Kekerasan; Kematangan; Beragama 


\section{A. Pendahuluan}

Pada hakekatnya tidak satu pun agama di dunia ini yang secara normatif mengajarkan kepada umatnya untuk melakukan tindak kekerasan terhadap sesama manusia, meskipun terhadap orang atau pun kelompok orang yang berbeda agama. Secara ideal, agama dan kekerasan dipandang sebagai memiliki jurang pemisah yang lebar. Keduanya diandaikan sebagai dua hal yang saling bertentangan. Kekerasan diasumsikan sebagai anti-tesis agama, dan juga sebaliknya.

Namun dalam kenyataannya, agama yang oleh para pemeluknya diyakini mengandung nilai-nilai luhur dan mengajarkan kedamaian itu, sering kali justru dijadikan sebagai alat pembenar bagi sikap dan perilaku kekerasan (violence) dalam upaya memaksakan kehendak. Dalam konteks demikian, tindak kekerasan dilakukan dengan mengatasnamakan agama.

Perilaku kekerasan atas nama agama itu tidak menjadi monopoli kelompok penganut agama tertentu, tetapi kenyataannya dilakukan pula oleh penganut berbagai agama. Dalam hal ini banyak orang lalu bertanya, bagaimana mungkin agama memicu tindakan kekerasan? Bukankah agama pada dasarnya mengajarkan hal yang sebaliknya, yaitu perdamaian? Mengapa dalam faktanya justru banyak kekerasan yang dilakukan atas nama agama?

Ironis memang, karena agama di satu sisi mengajarkan dan mendambakan masyarakat yang religius, penuh kedamaian, saling mencintai, saling mengasihi dan saling tolong menolong; namun di sisi yang lain kondisi obyektif masyarakat jauh dari tatanan ideal agama dimaksud. Agama laksana pisau yang bermata dua. Di satu sisi mengajak manusia kepada bentuk kehidupan yang damai harmonis; tetapi pada saat bersamaan mengakibatkan ketegangan dan bahkan kekerasan di antara para pengikutnya.

Dakwaan terhadap agama sebagai yang turut berperan dalam memicu konflik dan kekerasan, baik intern maupun antar umat bergama memang sulit dibantah. Hal itu antara lain terlihat dalam fenomena paling kontroversial di Indonesia mutakhir, yaitu lahir dan berkembangnya satu gerakan yang dikenal sebagai FPI (Front Pembela Islam) dengan segala aktivitasnya. Sisi kontroversial 
dari FPI ini bukanlah komitmen dan tekadnya untuk menegakkan moralitas keislaman dan membasmi kemungkaran (nahi munkar) berbasis pemahaman agama, namun lebih pada aksi-aksi yang mereka lakukan karena menjadikan kekerasan sebagai dasar strategi gerakannya. Sejak awal kelahirannya hingga saat ini, aktivitasaktivitas FPI banyak menghiasi media massa di Indonesia karena kekerasan yang dilakukannya.

Di luar problematika sosial-budaya-politik-ekonomi dan ideologi yang mendasari perilaku keras dalam beragama, kesediaan dan kesadaran seseorang untuk berkomitmen kepada agamanya -termasuk yang dilakukan dengan jalan kekerasan- sangat berhubungan dengan kematangan (maturity) dalam beragama. Kematangan beragama yang dimaksud adalah kapasitas internalisasi (pemahaman) dan eksternalisasi (ekspresi sesuai kondisi sosialbudaya) yang dimiliki seseorang sesuai dengan konteks psikologis dan historis kehidupannya sebagai pemeluk agama.

Berangkat dari beberapa pernyataan asumtif di atas, maka tulisan berikut akan mencoba mencermati tiga hal sekaligus, yaitu bagaimana fenomena kekerasan agama serta manifestasinya sebagaimana yang dilakukan oleh FPI. Lalu bagaimana hubungannya dengan kematangan beragama. Tulisan ini diharapkan memberikan sebuah perspektif tentang kekerasan agama yang tidak melulu diarahkan kepada kondisi sosial-budaya-politik dan ideologi, namun juga dilihat hubungannya dengan kondisi psikologi setiap orang.

\section{B. Kekerasan Agama: Aib yang Tak Mudah Dibantah}

Kata kekerasan yang dalam bahasa Arab sering disebut dengan khusyunat, dan dalam bahasa Inggris disebut dengan violence yang berarti; "suatu tindakan yang bersandar pada penggunaan ketegasan ekstra”. ${ }^{1}$ Definisi yang lain menyebut kekerasan sebagai "Perilaku yang bertentangan dengan kelembutan dan sesuatu yang natural”.

Sebenarnya konsep 'kekerasan' itu sendiri tidaklah tegas, tidak jauh berbeda dan bahkan mirip dengan konsep-konsep abstrak lainnya seperti kebebasan, toleransi, reformasi dan lain

${ }^{1}$ Ismail SM dan Abdul Mukti (ed.), Pendidikan Islam, Demokratisasi dan Masyarakat Madani, (Yogyakarta: Pustaka Pelajar, 2000), h.43. 
sebagainya yang dalam definisinya cenderung berkarakter konotatif dan subyektif. Karena subyektif, maka terdapat bermacam definisi terhadap konsep kekerasan. Karena subyektif ini pula, maka kekerasan sering dijelaskan tidak dengan definisi namun dengan kategori, karakter dan ciri-ciri, khususnya ciri dari perilaku manusia yang tergolong 'keras'.

Mengapa manusia bisa melakukan kekerasan? Tidakkah secara fitrah setiap orang mendambakan kedamaian, harmoni dan ketentraman? Untuk menjawab pertanyaan ini, secara umum digunakan beberapa teori, antara lain; 1) teori belajar aktor, 2) teori instink, 3) teori kepribadian, 4) teori kognitif, dan 5) teori frustasi agresi.

\section{Teori Belajar Sosial.}

Teori ini menyatakan bahwa kekerasan yang dilakukan manusia dipelajari dari komunitas sosialnya. Sebagian besar perilaku individu diperoleh sebagai hasil belajar melalui pengamatan atas perilaku yang ditampilkan oleh individu lain yang menjadi model. ${ }^{2}$ Contohnya, kegiatan demonstrasi yang dilanjutkan dengan tindakan anarkis di suatu tempat (misalnya membakar ban di tengah jalan, merobohkan pintu gerbang, bentrok dengan aparat keamanan, dan sebagainya) dapat menjadi model perilaku kekerasan bagi para demonstran di tempat lain.

\section{Teori Instink}

Teori ini berasal dari psikolog terkenal, Sigmund Freud. Teori ini menegaskan bahwa timbulnya perilaku kekerasan adalah karena instink manusia sendiri. Dengan teori ini diasumsikan bahwa semua orang mempunyai kecenderungan untuk melakukan kekerasan. Semula Freud mengemukakan bahwa perilaku kekerasan itu berkaitan erat dengan energi libido seksual. Jika instink seksual ini mengalami hambatan maka timbullah perilaku kekerasan. Selanjutnya Freud mengemukakan adanya dikotomi energi positif dan energi destruktif yang secara biologis akan mewujud dalam perilaku nyata. Jika energi destruktif mengarah ke luar maka menjadi pemicu perilaku kekerasan terhadap orang lain, sedangkan

${ }^{2}$ Daryl J. Bem, Social Psychology in the Seventies, (Belmot, California: Broke \& Cole, 1998), h. 258. 
jika mengarah ke diri sendiri maka dapat mendorong keinginan untuk menyakiti diri sendiri atau perilaku bunuh diri.

\section{Teori Kepribadian}

Teori ini menyatakan bahwa perilaku kekerasan terbangun secara psikis dalam diri seorang anak (proses pembentukan watak). Sifat-sifat kepribadian sebagai sifat internal berkorelasi dengan perilaku kekerasan termasuk emosi. ${ }^{3}$ Anak yang mengalami gangguan seperti cepat marah dan mudah menyerang cenderung mengem-bangkan pola perilaku kekerasan pada usia selanjutnya.

\section{Teori Kognitif.}

Konsep dasar teori kognitif mengacu pada kegiatan mental yang merupakan dialektika faktor-faktor seperti persepsi, pikiran, intensi, perencanaan, keterampilan, dan perasaan. Teori kognitif menekankan pentingnya interaksi resiprokal faktor-faktor individu sebagai penentu perilaku kekerasan. ${ }^{4}$

\section{Teori Frustasi-Agresi.}

Teori ini menyatakan bahwa setiap tindakan agresi dan kekerasan pada akhirnya dapat dilacak penyebabnya dalam kaitannya dengan frustasi. ${ }^{5}$ Terjadinya frustasi adalah jika seseorang tidak dapat memiliki sesuatu yang diinginkan pada waktu orang tersebut benar-benar memerlukannya.

Pertanyaan penting pertama yang harus diajukan berkaitan dengan perilaku kekerasan adalah apakah yang mendorong manusia melakukan tindakan kekerasan? Jawaban terhadap pertanyaan ini diharapkan akan mengantarkan pada pengertian tentang perilaku kekerasan. Menurut T. Robert Gurr, di dalam kompleksitas motivasi manusia, para neurofisiologis menemukan dua sistem hasrat (appetitive system) sebagai pembentuk motivasi yang terjadi pada manusia. Stimulasi dari salah satu sistem ini menghasilkan perasaan gembira, kepuasan, dan cinta. Stimulasi sistem lainnya menghasilkan sensasi kecemasan, teror, depresi, dan kemarahan.

${ }^{3}$ David C. McClelland, The Achievement Motive, (New York: Appleton-Century Crofts, 1996), h.112.

${ }^{4}$ Anita E. Woolfolk, Educational Psychology, (New York: Allyn and Bacon Inc., 1993), h. 82.

${ }^{5}$ S. Schacter, The Psychology of Affiliation, (London: Tavistock Publication, 1961), h.112. 
Perasaan-perasaan ini mewarnai persepsi manusia tentang dunia dan mendorong tindakan-tindakannya. ${ }^{6}$

Namun dalam perkembangannya, lingkungan manusia berubah sementara apa yang dipelajari manusia tidak selalu sesuai untuk menghasilkan kepuasan dirinya. Menghadapi kenyataan yang demikian manusia akan menjadi frustasi. Frustasi yang dialami manusia kemungkinan akan menimbulkan tindakan agresi. Hubungan frustasi-agresi menyebabkan terjadinya dinamika psikologis untuk hubungan antara intensitas deprivasi dan potensi bagi kekerasan kolektif. Menurut T. Robert Gurr menyebut hal ini sebagai deprivasi relatif (relative deprivation) yaitu ketegangan yang terjadi akibat suatu kesenjangan antara yang seharusnya (ought) dan yang sebenarnya (is) dalam kepuasan nilai kolektif, dan kesenjangan ini lalu mendorong manusia untuk melakukan kekerasan. ${ }^{7}$

Menurut Jack D. Douglas dan F.C. Waksler istilah kekerasan digunakan untuk menggambarkan perilaku, baik yang terbuka (overt) atau tertutup (covert), baik yang bersifat menyerang (offensif) atau bertahan (deffensive), yang disertai penggunaan kekuatan kepada orang lain. ${ }^{8}$ Dari pendapat tersebut dapat diidentifikasi adanya empat jenis kekerasan: (1) kekerasan terbuka, kekerasan yang dapat dilihat, seperti perkelahian; (2) kekerasan tertutup, kekerasan tersembunyi atau tidak dilakukan secara langsung, seperti mengancam; (3) kekerasan agresif, kekerasan yang dilakukan tidak untuk perlindungan, tetapi untuk mendapatkan sesuatu, seperti perampokan; dan (4) kekerasan defensif, kekerasan yang dilakukan sebagai tindakan perlindungan diri.

Dilihat dari bentuk dan jenisnya, kekerasan atas nama agama banyak macam dan ragamnya, mulai dari yang paling "kecil" dan "sederhana" seperti memukul anak agar taat kepada orang tua, agar anak menunaikan salat, sampai yang besar seperti angkat senjata melawan kelompok yang dianggap memusuhi agamanya. Dilihat dari ruang kejadian, kekerasan atas nama agama bisa terjadi di ruang domestik seperti kekerasan terhadap anak dan istri, dan bisa juga di

${ }^{6}$ Thomas Susanto (ed.), Teori-Teori Kekerasan, (Jakarta: Ghalia Indonesia dan Universitas Kristen Petra, 2002), h. 64.

${ }^{7}$ Ibid., h. 65.

${ }^{8}$ Ibid., h. 11. 
ruang publik seperti menghancurkan tempat-tempat yang dianggap sarang maksiat. Semua ini bisa dikategorikan sebagai kekerasan atas nama agama.

Dalam hubungannya dengan sejarah agama, berbagai momen sejarah menunjukkan betapa agama mudah menjadi alat provokasi dalam menimbulkan ketegangan dan kekerasan baik intern maupun antar umat beragama. Berbagai penelitian menunjukkan, kekerasan para pemeluk agama ini secara umum dilatarbelakangi oleh dua sikap keberagamaan berikut: (1) memonopoli kebenaran ajaran agamanya, sementara ajaran agama lain diberi label tidak benar. Sikap seperti ini, dapat memicu umat agama lain untuk mengadakan perang suci atau jihad dalam rangka mempertahankan agamanya; (2) merasa benar sendiri (dogmatis) sehingga tidak ada ruang untuk melakukan dialog yang kritis dan bersikap toleran terhadap agama lain. Dua sikap keagamaan seperti itu membawa implikasi adanya sikap tidak peduli terhadap keberagamaan orang lain. Sikap ini pada akhirnya akan menyebabkan keretakan hubungan antar umat beragama.

Dalam kenyataannya, perilaku kerasyang dilandaskan kepada agama ini memiliki variasi yang cukup beragam. Secara kategoris, variasi yang dimaksud antara lain adalah: Pertama, kekerasan yang berlangsung dalam ranah agama yang sama. Dari sudut aktor yang terlibat, terdapat variasi-variasi, antara lain: (a) kekerasan yang melibatkan ormas dalam komunitas agama yang sama, (b) kekerasan yang melibatkan negara yang bertindak atas nama agama resmi dalam merepresi "aliran sesat" dalam satu agama, (c) kekerasan yang melibatkan komunitas dari agama yang sama, (d) kekerasan yang melibatkan institusi pemegang otoritas agama atas warga dari komunitas agama yang sama. ${ }^{9}$

Kedua, kekerasan yang melibatkan agama yang berbeda. Dari sudut aktor, terdapat variasi pola pula: (a) kekerasan yang melibatkan ormas satu agama atas komunitas dari agama lain. (b) kekerasan yang melibatkan ormas dari komunitas agama yang berbeda, (c) kekerasan atas kelompok agama yang melibatkan negara melalui pengaturan tertentu. ${ }^{10}$

${ }^{9}$ Coenelis Lay, "Kekerasan atas Nama Agama: Perspektif Politik" dalam Jurnal Sosial-Politik, Vol. 13, No. 1, Juli 2009, h. 4-5

${ }^{10}$ Ibid. 
Ketiga, kekerasan satu kelompok agama atas kelompok lain yang melakukan aktivitas yang dinilai tidak sesuai dengan ajaran agama. Variasi pola juga ditemukan di sini antara lain berupa: (a) kekerasan dilakukan oleh ormas agama atas aktivitas-aktivitas yang dianggap sebagai simbol pelanggaran ajaran agama, (b) kekerasan atas nama agama oleh kelompok masyarakat yang ditujukan pada aktivitas-aktivitas yang didakwa sebagai simbol pelanggaran ajaran agama. ${ }^{11}$

Beberapa kalangan mencoba mengaitkan bermacam bentuk kekerasan agama dengan bangkitnya fundamentalisme agama. Dalam konteks fundamentalisme agama, seseorang atau kelompok, ketika terhalang atau tidak dapat mengekspresikan keinginannya, atau cita-cita sosial-politiknya, akhirnya melakukan berbagai bentuk ekstrimisme dan seringkali diikuti oleh kekerasan sebagai reaksi terhadap terhalangnya upaya mengekspresikan cita-cita sosial dan politiknya. Sebagaimana yang dinyatakan Armstrong, fundamentalisme merupakan salah satu fenomena paling mengejutkan pada akhir abad ke-20. Ekspresi fundamentalisme ini tidak jarang cukup mengerikan, seperti penembakan terhadap jamaah yang sedang salat di masjid, membunuh dokter dan perawat yang sedang bertugas di rumah sakit, membunuh presiden, dan bahkan mampu menggulingkan pemerintahan yang kuat. ${ }^{12}$

Fenomena Kekerasan atas nama agama ini ternyata juga tidak luput mewarnai sejarah bangsa Indonesia. Tentang kekerasan agama di Indonesia ini, sudah banyak mendapatkan analisis dan respon yang bervariasi dari para pengkaji agama-agama, baik dari Indonesia sendiri maupun dari luar Indonesia. Azyumardi Azra misalnya-sebagaimana dikutip oleh Cornelis Lay - menggunakan perspektif politik dalam memahami persoalan ini. Menurut Azyumardi, kekerasan atas nama agama telah ada pasca kemerdekaan dengan munculnya DI/TII, satu gerakan politik yang menggunakan agama sebagai justifikasi dalam usaha untuk mewujudkan cita-cita politiknya. Sejak jatuhnya Soeharto, kelompok ini muncul lebih visible, lebih militan, dan vokal. Hal ini semakin dikuat oleh kehadiran

\footnotetext{
${ }^{11}$ Ibid.

${ }^{12}$ Arnold Mattew, Culture and Anarchy, (New York: Macmillan, 2006), h. 26.
} 
media massa, khususnya media elektronik seperti TV yang banyak memberikan liputan atas sepak-terjang kelompok sejenis ini. ${ }^{13}$

Lebih jauh menurut Azyumardi Azra, aksi kekerasan ini bisa terjadi karena faktor agama saja dan bisa juga karena politik; bisa bertitik tolak dari pemahaman keagamaan tertentu kemudian diisi oleh muatan politik atau sebaliknya, muatan politik lebih dulu baru diberikan justifikasi agama. Secara umum biasanya perilaku kekerasan ini diawali dari satu agenda politik tertentu kemudian mencari justifikasi dari ayat-ayat al-Quran atau Hadis atau pandangan ulama tertentu. Dengan pemahaman ini mendorong mereka melakukan tindakan politik tertentu, termasuk tindakan kekerasan. ${ }^{14}$

\section{FPI dan Gerakan "Membela Islam”}

Satu diantara gerakan sosial di Indonesia yang sangat sering diidentikkan dengan kekerasan adalah Front Pembela Islam (FPI). FPI adalah sebuah organisasi massa Islam bergaris keras yang berpusat di Jakarta. FPI dideklarasikan pada 17 Agustus 1998 (atau 24 Rabiuts Tsani 1419 H) di halaman Pondok Pesantren al-Um, Kampung Utan, Ciputat, Jakarta Selatan, oleh sejumlah Habaib, Ulama, Mubalig dan aktivis Muslim serta disaksikan ratusan santri yang berasal dari daerah Jabotabek. Pendirian organisasi ini hanya empat bulan setelah Presiden Soeharto mundur dari jabatannya, karena pada saat pemerintahan Orde Baru presiden tidak mentolerir tindakan ekstrim dalam bentuk apapun.

Secara ideal, organisasi ini dibentuk dengan tujuan menjadi wadah kerja sama antara ulama dan umat dalam menegakkan Amar Ma'ruf dan Nahi Munkar. Latar belakang pendirian FPI sebagaimana diklaim oleh organisasi tersebut antara lain:

1. Adanya penderitaan panjang umat Islam di Indonesia karena lemahnya kontrol sosial penguasa sipil maupun militer akibat banyaknya pelanggaran HAM yang dilakukan oleh oknum penguasa.

2. Adanya kemungkaran dan kemaksiatan yang semakin merajalela di seluruh sektor kehidupan.

\footnotetext{
${ }^{13}$ Lay, Kekerasan..., h. 14-15.

${ }^{14}$ Ibid.
} 
3. Adanya kewajiban untuk menjaga dan mempertahankan harkat dan martabat Islam serta umat Islam.

FPI memiliki struktur organisasi yang terdiri atas: Dewan Pimpinan Pusat, Ketua Majelis Syura; Ketua Majelis Tanfidzi. Dewan Pimpinan Daerah, sebagai pengurus organisasi berskala Provinsi: Dewan Pimpinan Wilayah, sebagai pengurus organisasi berskala Kota/Kabupaten; dan Dewan Pimpinan Cabang, sebagai pengurus organisasi berskala kecamatan.

Menurut tokoh FPI, pada era reformasi, pemerintah tidak dapat mengendalikan terjadinya tindak kemaksiatan, seperti perjudian, narkoba, minuman keras, dan beroperasinnya tempattempat maksiat secara terbuka. Oleh karena itu, kelompok ini merasa wajib mengambil inisiatif membantu pemerintah untuk memerangi kemaksiatan tersebut. ${ }^{15}$ Sebagai bagian dari masyarakat, FPI merasa memiliki kewajiban untuk berperan serta dalam memberikan kontribusi positif untuk kemajuan bangsa. ${ }^{16}$

Sesuai dengan latar belakang pendiriannya, maka FPI mempunyai sudut pandang yang menjadi kerangka berfikir organisasi (visi), bahwa penegakan amar ma'ruf nahi munkar adalah satu-satunya solusi untuk menjauhkan kezaliman dan kemunkaran. Tanpa penegakan amar ma'ruf nahi munkar, mustahil kezaliman dan kemunkaran akan sirna dari kehidupan umat manusia di dunia.

FPI bermaksud menegakkan amar ma'ruf nahi munkar secara káffah di segenap sektor kehidupan, dengan tujuan menciptakan umat yang hidup dalam baldah thoyyibah dengan limpahan keberkahan dan keridhoan Allah. Sifat organisasi ini mandiri dan tidak menjadi bagian dari ormas/orsospol manapun juga. Rambu utama yang digunakan adalah: Allah swt sebagai tujuan kami, Muhammad saw adalah teladan kami, al-Qur'an adalah pedoman kami dan syahid adalah cita-cita kami. Sementara itu semboyan dari FPI adalah hidup mulia atau mati syahid. ${ }^{17}$

FPI menjadi sangat terkenal karena aksi-aksinya yang kontroversial sejak tahun 1998, terutama yang dilakukan oleh

${ }^{15}$ Habib Muhammad Riziq Shihab, Dialog FPI-Amar Ma'ruf Nahi Munkar, (Jakarta: Ibnu Saidah, 2008), h. 89.

${ }^{16}$ Ibid., h. 90.

${ }^{17}$ Pedoman Front Pembela Islam (AD/ART), t.t 
laskar paramiliternya yakni Laskar Pembela Islam. Rangkaian aksi penutupan klub malam, tempat pelacuran dan tempat-tempat yang diklaim sebagai tempat maksiat, ancaman terhadap warga negara tertentu, penangkapan (sweeping) terhadap warga negara tertentu, konflik dengan organisasi berbasis agama yang lain adalah wajah FPI yang paling sering diperlihatkan dalam media massa.

Mulai tahun 1998 hingga tahun 2014 tidak kurang dari 64 kali aksi kekerasan kontroversial yang dilakukan oleh FPI. ${ }^{18}$ Jenis aksi yang paling menonjol dan biasanya menjadi santapan media massa adalah menyerbu tempat-tempat yang dianggap maksiat, bentrok dengan aparat atau warga setempat, melakukan demo anarkis melawan tokoh atau lembaga yang tidak disukai, dan lain sejenisnya. Tidak mengherankan apabila kemudian bagi banyak kalangan FPI adalah simbol bagi perilaku kekerasan dalam mendakwahkan agama.

Secara obyektif harus disebut pula bahwa disamping aksiaksi kontroversial tersebut FPI juga melibatkan diri dalam aksi-aksi kemanusiaan antara lain pengiriman relawan ke daerah bencana tsunami di Aceh, bantuan relawan dan logistik saat bencana gempa di Padang dan beberapa aktivitas kemanusiaan lainnya. Meskipun demikian, harus diakui bahwa sebagian besar aktivitas FPI berhubungan dengan perilaku kekerasan.

\section{Korelasi Kekerasan dan Kematangan Beragama}

Terjadinya kekerasan biasanya merupakan interaksi proses psikologis yang melibatkan banyak unsur: sugesti, imitasi dan tekanan emosi. Gustave le Bon, seorang pakar sosiologi kerusuhan sosial, menyatakan bahwa manusia seperti binatang yang memiliki kecenderungan untuk ikut-ikutan. Seperti kawanan kuda, ada yang patuh, ada pula yang melawan tuannya tatkala mau dikandangkan. Le Bon tidak percaya bahwa para pelaku kekerasan itu bergabung karena didorong oleh pilihan yang benar-benar rasional, dengan emosi yang terkontrol, atau tindakan sadar (reflexive behavior). ${ }^{19}$

${ }^{18}$ Lihat antara lain dalam http://id.wikipedia.org/ wiki/ Daftar_aksi_Front_ Pembela_ Islam; diakses tanggal 27 Oktober 2014.

${ }^{19}$ Moeslim Abdurrahman, Islam sebagai Kritik Sosial, (Jakarta: Erlangga, 2003), h. 60-65. 
Kenyataan ini mengindikasikan bahwa akar kekerasan hakikatnya berada dalam dunia psikis seseorang, khususnya sejauh mana ia mampu mengontrol emosi dan mendayagunakan rasionya serta setangguh apa dirinya menghadapi berbagai pengaruh dari luar. Dalam konteks kepemelukan agama dapat dikatakan kematangan psikis seseorang akan berimbas kepada kematangannya dalam beragama, lalu pada gilirannya kematangan beragama akan memandunya dalam berperilaku keagamaan sehingga jauh dari ekspresi-ekspresi destruktif seperti kekerasan.

Kematangan psikis sendiri merupakan satu kondisi dimana differensiasi dan integrasi antara badan, jiwa dan mental telah sempurna dan terkonsolidasi, serta ketika telah ada kesiapan dari individu dalam menghadapi tuntutan kehidupan. ${ }^{20}$ Kepribadian yang matang tidak tergantung pada usia, demikian juga dengan kematangan beragama, yang tidak selamanya tergantung pada kematangan fisik atau usia seseorang. Tidak selamanya orang yang sudah dewasa atau tua usianya pasti memiliki kematangan beragama, sebaliknya tidak mustahil seorang yang belum begitu tua (remaja misalnya) dapat memiliki kematangan beragama. ${ }^{21}$

Walter Houton Clark, seorang ahli psikologi agama, menyatakan bahwa ciri-ciri keberagamaan yang matang adalah sebagai berikut: Pertama, lebih kritis, kreatif, dan otonom dalam beragama; Kedua, memperluas perhatiannya terhadap hal-hal di luar dirinya; Ketiga, tidak puas semata-mata dengan rutinitas ritual dan verbalisasinya. ${ }^{22}$

Dengan lebih detil, ahli psikologi agama lain, Gordon Allport menguraikan ciri-ciri kematangan beragama dalam beberapa kriteria berikut: ${ }^{23}$ Pertama, berpengetahuan luas dan rendah hati (well-differentiated and self critical). Orang beragama dengan ciri ini mengimani dan memiliki kesetiaan yang kuat terhadap agamanya, namun juga mengakui memiliki "kekurangan" untuk diperbaiki sehingga mau belajar kepada siapapun termasuk kepada pemeluk

${ }^{20}$ Djami'atul Islamiyah, "Studi Psikologis tentang Kematangan Beragama" dalam Jurnal Attarbiyah, Vol. 2, No.1, 2006, h 17.

${ }^{21}$ Ibid.,h. 18.

${ }^{22}$ Walter Houston Clark, The Psychology of Religion: An Introduction to Religious and Behavior (New York: The MacMillan Company, 1968), h. 242-243.

${ }^{23}$ Ibid., h. 244-247. 
agama lain. Intinya, keberagamaan yang matang menggunakan nalar sebagai faktor integral yang berfungsi secara dinamis dalam beragama.

Kedua, menjadikan agama sebagai kekuatan motivasi (motivational force). Orang yang matang dalam beragama menjadikan agama sebagai tujuan dan kekuatan yang selalu dicari untuk mengatasi setiap masalah yang selanjutnya membawa pada transformasi diri.

Ketiga, memiliki moralitas yang konsisten (moral consistency). Orang yang beragama matang memiliki perilaku yang sejalan dengan nilai-nilai moral secara yang konsisten dalam perilaku nyata sehari-hari.

Keempat, pandangan hidup yang komprehensif (comprehensiveness), yang intinya adalah toleransi. Orang yang beragama matang memiliki keyakinan kuat akan agamanya tetapi juga mengharuskan dirinya untuk hidup berdampingan secara damai dan harmonis dengan orang lain yang berbeda dengan dirinya. Konflik dan kekerasan tentu bukan bagian dari kehidupannya karena toleransi merupakan visi hidupnya.

Kelima, pandangan hidup yang integral (integral). Kriteria ini melibatkan refleksi dan harmoni, serta hidup yang berguna. Orang yang beragama dengan matang, sejalan dengan prinsip keempat sebelumnya, memiliki visi hidup yang harmoni atau damai. Ia juga mengorientasikan hidupnya agar dapat berguna bagi orang lain.

Keenam, heuristic. Maksud dari kriteria ini adalah bahwa orang yang beragama matang selalu mencari kebenaran dan memahami pencapaian sementara tentang keyakinannya itu, yang menjadikannya seorang "pencari” selamanya. Orang yang beragama matang memiliki kerendahan hati dan keterbukaan atas pandanganpandangan keagamaan baru dan menjadikan perkembangan atau dinamika keagamaan sebagai sebuah pencarian terhadap kebenaran yang sejati.

Sementara itu William James yang dianggap sebagai bapak psikologi agama memberikan kriteria orang yang beragama matang sebagai berikut; Pertama, kesadaran akan eksistensi Tuhan, maksudnya adalah bahwa orang yang beragama matang selalu 
tersambung hati dan pikirannya dengan Tuhan. Karena selalu tersambung dengan Tuhan, perilaku orang yang beragama matang akan melahirkan kedamaian, ketenangan batin yang mendalam dan terhindar dari keburukan-keburukan hidup.

Kedua, kedekatan dengan Tuhan dan penyerahan diri padaNya. Poin kedua ini merupakan konsekwensi dari yang pertama, dimana orang beragama matang secara sadar dan tanpa paksaan menyesuaikan hidupnya dengan kehendak Tuhan, yakni kebajikan, karena Tuhan adalah Yang Maha Baik. Orang yang beragama matang terbebas dari ego yang selalu membisikkan orang pada kejahatankejahatan, baik secara intra maupun interpersonal.

Ketiga, penyerahan diri sebagaimana dalam poin kedua melahirkan rasa bahagia dan kebebasan. Ia akan mengaktifkan energi spiritual dan menggerakkan karya spiritual. Orang yang beragama matang memiliki gairah hidup, dan memberikan makna dan kemuliaan baru pada hal-hal yang lazimnya dianggap biasabiasa saja. Agama menjadi sumber kebahagiaan, sehingga orang yang beragama matang menjalani kehidupannya dengan penuh kebahagiaan.

Keempat, orang yang beragama matang mengalami perubahan dari emosi menjadi cinta dan harmoni. Orang yang beragama matang mencapai perasaan tenteram dan damai, dimana cinta mendasari seluruh hubungan interpersonalnya. Oleh karena itu, orang beragama matang bebas dari rasa benci, prejudice, permusuhan, dan lain-lain. Seorang Sufi, Bikkhu dan Bikkhuni, Romo, dan yang sejenis masuk ke dalam tipe orang yang beragama matang ini.

Secara lebih ringkas Erich Fromm dalam pembahasan tentang kematangan beragama ini membandingkan antara keberagamaan otoriter dan keberagamaan humanis. Keagamaan otoriter adalah keberagamaan yang diperoleh dari yang lain (luar) dan bersifat tirani dalam diri seseorang, sedangkan keberagamaan humanis adalah keagamaan yang muncul dari pendirian dan keyakinan terdalam, kerinduan akan nilai agama dalam dirinya sehingga bersifat humanis. Keberagamaan tipe kedua inilah yang dimaksud Fromm sebagai keagamaan yang matang. ${ }^{24}$

${ }^{24}$ Ibid., h. 255 . 
Tingkatan kematangan dalam beragama pada gilirannya akan membentuk modus beragama seseorang. Secara teoritis modus keberagamaan ini biasa diklasifikasi dalam tiga mode, yaitu ekslusif, inklusif dan pluralis.

Pertama, keberagamaan eksklusif. Orang atau kelompok orang yang memiliki paradigma ini berpandangan bahwa seseorang tidak akan selamat kecuali mengikuti iman yang dia akui dan memeluk agama yang dia peluk. Agama-agama lain boleh jadi memiliki banyak kebenaran dan kebaikan, tetapi agama-agama lain tersebut dianggap tidak bisa menjadi jalan keselamatan. ${ }^{25}$

Ekspresi keberagamaan penganut kelompok ini adalah tertutup, anti dialog, konservatif, cenderung fundamentalis, intoleran, apologis, dogmatis, sering menonjolkan sisi perbedaan dan menutup sisi persamaan saat berhadapan dengan 'yang lain'. Pendekatan yang dipakai oleh kelompok ini bersifat subyektif, yakni menilai kelompok lain berbeda dari perspektif kelompoknya. Kelompoknya dipandang paling benar, dan orang lain akan memperoleh keselamatan jika bergabung dengan kelompoknya, meyakini keyakinannya; sedangkan keyakinan di luar dirinya dianggap keliru.

Hal demikian oleh Arkoun disebut sebagai sakralisasi terhadap pemikiran keagamaan. Bahkan pemahaman agama itu dianggap sebagai sama dengan agama yang wajib diikuti, sehingga keberagamaan mengalami stagnasi dan akhirnya terjadilah marginalisasi dan alienasi agama dalam realitas empirik. Proses ini oleh Fazlur Rahman disebut sebagai proses "Ortodoksi". ${ }^{26}$ Paradigma ini sangat jauh dari kemungkinan terbukanya peluang dialog, interaksi dan toleransi antar umat beragama.

Kedua, keberagamaan inklusif. Kelompok inklusif membedakan antara keselamatan dan Tuhan dalam tradisi agamaagama lain. Penganut inklusif lebih mengedepankan pemahaman ajaran agama secara kontekstual, esensial dan memahami makna, sehingga implementasi ajaran agama mempertimbangkan dan

${ }^{25}$ J.B. Bana Wiratima SJ, Sains Perspektip Gereja Katolik, (Yogyakarta: Dian/ Anter Fidei, 1993), h. 4.

${ }^{26}$ Fazlurrahman, Islam, (Chicago: University of Chicago Press, 1979), h. 105. 
memperhatikan konteks ruang dan waktu, situasi serta kondisi sosio-kultural dimana agama tersebut berada.

Setidaknya ada tiga gagasan utama yang melekat pada penganut inklusif yaitu: (1) substansi keimanan dan peribadatan lebih penting dari pada formalitas dan simbolisme keagamaan yang bersifat literal; (2) pesan-pesan agama yang bersifat abadi dalam esensinya dan universal dalam maknanya harus selalu ditafsirkan ulang oleh masing-masing generasi umat sesuai dengan konteks zaman yang dihadapi; (3) kebenaran mutlak hanyalah milik Tuhan, maka tidak seorangpun yang dapat memastikan bahwa pemahamannya terhadap pesan Tuhan adalah paling benar, lebih benar atau lebih baik dari pada pemahaman orang lain. Karenanya kelompok ini sangat menekankan pentingnya toleransi terhadap umat seagama maupun antar umat beragama karena perbedaan agama, budaya maupun politik dipandang sebagi fitrah kemanusiaan yang bersifat universal dan oleh karenanya perlu direspon dengan penuh kesadaran.

Ketiga, keberagamaan pluralis. Paradigma ini berbeda secara substansial dengan kelompok inklusif, terlebih dengan kelompok eksklusif. Dalam pandangan kelompok pluralis, semua agama dengan cara masing-masing menempuh jalan keselamatan menuju yang mutlak (the ultimate), menuju Allah.

Tanpa harus bertele-tele menyusun argumen, kerangka teoritis kematangan beragama di atas apabila dihubungkan dengan 'jalan kekerasan' yang ditempuh oleh FPI akan mengarah kepada kesimpulan bahwa model beragama yang dijalankan oleh FPI, khususnya dalam konteks sosial, menunjukkan adanya ketidakdewasaan atau kekurangmatangan dalam beragama. Kekurangmatangan tersebut dapat dilihat setidaknya dalam tiga hal berikut:

1. Melakukan sakralisasi pemikiran sendiri; merasa pemahaman dan penghayatannya sendiri terhadap agama sebagai satusatunya yang paling benar. Pemahaman lain dan modus beragamayangberbeda dianggapsebagaisebuah penyelewengan dari yang seharusnya, sehingga harus diluruskan, bahkan disingkirkan. 
2. Mengedepankan konflik dan kekerasan terhadap yang lain sebagai senjata untuk "membela agama". Sikap ini dapat dipastikan timbuldari asumsi bahwa 'yanglain' adalah ancaman terhadap agama, oleh karena itu tidak boleh ditoleransi.

3. Memaksa dengan kekerasan kepada 'yang lain' untuk mengikuti gaya beragama seperti dirinya.

Lebih jauh apabila dilihat dari kaca mata paradigmatik tentang keberagamaan seperti disebut sebelumnya, keberagamaan dalam model yang dikembangkan oleh FPI adalah keberagamaan ekslusif. Kenyataan ekslusif ini koheren dengan visi-misi dan sekaligus garis perjuangan yang diambil oleh FPI.

Sebenarnya tidak ada salahnya FPI mencanangkan visi amar ma'ruf nahi munkar, lalu merancang segala macam aktifitas sebagai misi dalam rangka menyukseskan visi dimaksud. Setiap muslim hakikatnya memiliki kewajiban yang sama untuk melakukan amar ma'ruf nahi munkar ini. Namun strategi pemaksaan dan kekerasan yang dilakukan oleh FPI kiranya perlu direvisi dan ditelaah kembali sehingga ditemukan formula aksi yang tepat dalam amar ma'ruf nahi munkar ini, tanpa harus melibatkan kekerasan. Dalam banyak ayat al-Qur'an dan beberapa Hadis telah disebut bahwa tugas seorang muslim kepada muslim yang lain adalah 'saling mengingatkan', 'saling bekerja sama', 'saling menasehati', tanpa harus memaksakan hasil, apalagi dengan kekerasan, karena bahkan Nabi pun menyatakan bahwa yang bisa dilakukannya hanyalah "mengajak dan memperingatkan", sementara hidayah dan keterbukaan hati adalah hak preogratif Allah.

Untuk bisa 'saling mengingatkan', 'saling menasehati' dan 'saling bekerja sama' tentunya diperlukan kematangan dalam beragama, khususnya kematangan emosional, kematangan intelektual dan kematangan sosial sebagaimana dipaparkan di atas. Dalam konteks ini, evaluasi kembali terhadap perilaku-perilaku kekerasan yang menunjukkan 'hilangnya kontrol emosional', 'kurangnya wawasan intelektual' dan 'rendahnya kualitas hubungan sosial' harus segera dilakukan.

Selain merugikan dalam konteks kehidupan sosial bersama, model keberagamaan sebagaimana dikembangkan oleh FPI ini seringkaijustrukontraproduktifdenganideal-idealyangdicanangkan 
sendiri oleh FPI sejak awal. Strategi kekerasan yang dikembangkan oleh FPI seringkali justru melahirkan stigma-stigma negatif, tidak hanya terhadap FPI namun juga terhadap Islam sendiri.

Mode-mode kekerasan sebagaimana dikembangkan oleh FPI ini dijadikan dasar argumentasi oleh mereka yang memusuhi Islam sebagai bukti bahwa Islam memang agama yang mendukung kekerasan. Robert Spencer misalnya, seorang ilmuwan anti-Islam dalam kajiannya terhadap fenomena kekerasan atas nama Islam, terutama terorisme, sampai pada kesimpulan bahwa kekerasan itu merupakan sublimasi dari keyakinan teologis yang mendalam dari pemeluknya. Kekerasan bukanlah ekspresi sampingan, melainkan ekspresi maha-dahsyat yang bersumber dari ajaran-ajaran yang terkandung dalam teks-teks keagamaan. Itulah wujud ekspresi dari kaum Muslim yang benar-benar menghayati ajarannya. Spencer menyatakan, bisa jadi di wilayah Islam terdapat kedamaian atau setidaknya tidak terjadi perang, namun Islam sesungguhnya mendeklarasikan perang terus-menerus antara orang-orang yang beriman dan orang-orang kafir. $^{27}$

\section{E. Penutup}

Islam adalah rahmatan lil ālamin, demikian kata mutiara yang sering dikutip dan pasti diyakini oleh setiap muslim. Meskipun demikian, seringkali al-Islāmu mahjūbun bil muslimīn, Islam, kebenaran, kebaikan dan keindahannya tidak terlihat karena terhalang oleh perilaku umat Islam sendiri.

Fenomena kekerasan agama, sebagaimana ditunjukkan dalam berbagai aksi FPI, adalah fenomena kekerasan yang lazim muncul dalam ranah-ranah kehidupan manusia yang lain. Hanya saja fenomena ini menjadi luar biasa karena agama dijadikan landasan dari aksi kekerasan, sementara setiap pemeluk agama meyakini

${ }^{27}$ Robert Spencer, Islam Unveiled Islam Ditelanjangi (Pertanyaan-Pertanyaan Subversif Seputar Doktrin dan Tradisi Kaum Muslim) (Jakarta: Paramadina, 2003), h. 2526. Pandangan Spencer ini berbeda dengan kesimpuplan Fazlur Rahman bahwa alQur'an pada hakikatnya adalah sebuah dokumen agamis dan etikyang punya tujuan praktis bagi penciptaan masyarakat yang baik dan adil secara moral. Masyarakat tipe ini haruslah terdiri dari manusia yang shaleh secara agama dengan kesadaran yang tajam dan kuat tentang Allah yang memerintahkan kebaikan dan melarang keburukan. Lihat Fazlurrahman, Islam, h. 195. 
bahwa agama adalah sumber harmoni, kedamaian dan ketentraman dalam hidup.

Problem dan konflik adalah sesuatu yang niscaya dalam kehidupan, termasuk dalam kehidupan beragama, khususnya yang menyangkut ranah sosial interaksi antar manusia. Namun problem dan konflik hendaknya menjadi pemicu perkembanganperkembangan baru yang kontributif terhadap peradaban manusia dan kemanusiaan, bukan menjadi awal dari perilaku kekerasan dan kehancuran. Untuk tujuan yang mulia ini, diperlukan pribadipribadi yang memiliki kematangan dalam beragama, yaitu mereka yang mendalam ilmunya, terkendali emosinya dan manusiawi perilakunya. Hanya dari pribadi-pribadi matang inilah nantinya wajah Islam yang sejati, Islam yang rahmatan lil alamin, akan lahir.[]

\section{Daftar Pustaka}

Abdurrahman, Moeslim, Islam sebagai Kritik Sosial, Jakarta: Erlangga, 2003.

Bem, Daryl J., Social Psychology in the Seventies, Belmot, California: Broke \& Cole, 1998.

Cornelis Lay, "Kekerasan Atas nama Agama: Perspektif Politik" dalam Jurnal Sosial-Politik, Vol. 13, No. 1, Juli 2009.

Djami'atul Islamiyah, "Studi Psikologis tentang Kematangan Beragama” dalam Jurnal Attarbiyah, Vol. 2, No.1, 2006.

Fazlurrahman, Islam, Chicago: University of Chicago Press, 1979.

Houston Clark, Walter, The Psychology of Religion: An Introduction to Religious and Behavior. New York: The MacMillan Company, 1968.

Mattew, Arnold, Culture and Anarchy, New York: Macmillan, 2006.

McClelland, David C., The Achievement Motive, New York: AppletonCentury Crofts, 1996.

Schacter, S., The Psychology of Affiliation, London: Tavistock Publication, 1961. 
Shihab, Habib Muhammad Riziq, Dialog FPI-Amar Ma'ruf Nahi Munkar, Jakarta: Ibnu Saidah, 2008.

SM, Ismail dan Mukti, Abdul (ed.)., Pendidikan Islam, Demokratisasi dan Masyarakat Madani, Yogyakarta: Pustaka Pelajar, 2000.

Spencer, Robert, Islam Unveiled Islam Ditelanjangi. (Pertanyaan-Pertanyaan Subversif Seputar Doktrin dan Tradisi Kaum Muslim), Jakarta: Paramadina, 2003.

Susanto, Thomas, (ed.), Teori-Teori Kekerasan, Jakarta: Ghalia Indonesia dan Universitas Kristen Petra, 2002.

Wiratima, Bana, SJ, JB. Sains Perspektip Gereja Katolik, Yogyakarta: Dian/ Anter Fidei, 1993.

Woolfolk, Anita E., Educational Psychology, New York: Allyn and Bacon Inc., 1993. 